\title{
Gambaran Psikologis Cinderella Complex Syndrome pada Perempuan Suku Banjar (Studi Deskriptif pada KAMMI Kota Banjarmasin)
}

\author{
Ayu Nurhafizah, Siti Faridah, dan Imadduddin \\ Universitas Islam Negeri Antasari Banjarmasin
}

\begin{abstract}
The cinderella complex syndrome is a network of attitudes and fears in women and makes them feel depressed, causing fearness to use their ability, thus their desire to always be taken care of and protected appeared. The purpose of this research is to know the psychological description of cinderella complex syndrome in women who joined KAMMI Banjarmasin which includes the forming process, factors, characteristics, and aspects. This is field research with descriptive qualitative approach in Banjarmasin with 2 subjects aged 20 and 21 years old. The data collecting methods used in this research is screening test using the scale of the cinderella complex syndrome, interviews, observation, and graphic tests (with analysis results of the tests that supervised by a psychologist). The result of this research indicates that the forming process of the cinderella complex syndrome is closely related to various childhood experiences. The influencing factors are culture, parenting, mass media, low self-esteem, and perception. The characteristics that apparent are lack of confidence, feel worthless, afraid to face challenges, hard to do everything by herself, often having psychosomatic, fear of failure, lazy to take a risk, and dependent. Aspects that seen are they expect directions from others, external self-control, low self-esteem, avoid challenges, and competitions. There are also aspects of emotions, cognitive, and social that has been successfully revealed through graphic test.
\end{abstract}

Keywords: psychological description; cinderella complex syndrome; banjar tribe; women; KAMMI.

\begin{abstract}
Abstrak
Cinderella complex syndrome adalah suatu jaringan sikap dan rasa takut yang dialami perempuan dan membuatnya merasa tertekan, menyebabkan ketakutan menggunakan kemampuan sehingga muncul keinginan untuk selalu dirawat dan dilindungi. Tujuan dari penelitian ini adalah untuk mengetahui gambaran psikologis cinderella complex syndrome pada perempuan suku Banjar yang tergabung dalam organisasi KAMMI Kota Banjarmasin yang meliputi proses terbentuk, faktor, ciri, dan aspek. Penelitian ini merupakan penelitian lapangan bersifat deskriptif kualitatif, dilakukan di Kota Banjarmasin dengan jumlah subjek sebanyak 2 orang berusia 20-21 tahun. Metode pengumpulan data yang digunakan adalah screening test menggunakan skala cinderella complex syndrome, wawancara, observasi, dan tes grafis (dengan analisis hasil tes yang disupervisi oleh psikolog). Hasil dari penelitian ini menunjukkan proses terbentuknya cinderella complex syndrome erat kaitannya dengan pengalaman masa kecil. Faktor yang memengaruhi adalah budaya, pola asuh, media massa, rendahnya harga diri, dan persepsi. Ciri-ciri yang terlihat adalah tidak percaya diri, merasa tidak berharga, takut menghadapi tantangan, sulit melakukan segala sesuatu sendiri, sering mengalami psikosomatis, sangat takut gagal, malas mengambil risiko, dan dependen. Aspek yang terlihat yakni mengharapkan pengarahan dari orang lain, kontrol diri eksternal,
\end{abstract}


rendahnya harga diri, serta menghindari tantangan dan kompetisi, juga terdapat aspek emosi, kognitif dan sosial yang berhasil diungkap melalui tes grafis.

Kata Kunci: gambaran psikologis; cinderella complex syndrome; suku banjar; perempuan; KAMMI.

Menurut agama Islam, manusia adalah makhluk Allah yang paling sempurna yang pernah diciptakan Allah, yang terdiri dari laki-laki dan perempuan. Seharusnya tidak ada ketimpangan pandangan terhadap laki-laki dan perempuan. Namun faktor sosial-budaya masih menempatkan perempuan lebih rendah dibandingkan laki-laki (Hapsah, 2014). Sistem patriarki yang berkembang luas dalam berbagai masyarakat menempatkan perempuan pada posisi yang tidak diuntungkan secara kultural, structural, dan ekologis (Huda). Dan masyarakat Banjar sendiri masih menganut sistem kekerabatan patrilineal yang menempatkan kedudukan laki-laki di atas daripada kedudukan perempuan (Salasiah, 2014). Hal ini juga diaminkan oleh salah satu peneliti dari pusat studi gender dan anak dari LP2M UIN Antasari Banjarmasin. Perempuan dipandang berdasarkan segi jenis kelaminnya dan kemudian seolah-olah mengharuskan perempuan berperan pada sektor domestik saja (Kumari).

Padahal dewasa ini, peran perempuan juga sangat diharapkan di masyarakat dan dengan banyaknya kesempatan bagi perempuan untuk berperan di masyarakat, tentunya tidak dapat dipungkiri bahwa akan ditemui pula beragam tantangan dalam segala prosesnya. Sangat perlu adanya peningkatan kualitas kepribadian. Salah satu unsur kepribadian yang dianggap paling penting adalah kemandirian. Karena kemandirian merupakan modal dasar bagi manusia dalam menentukan sikap dan perbuatan terhadap lingkungannya (Hapsah, 2014). Namun, faktanya dapat dilihat di lapangan bahwa tidak semua manusia khususnya perempuan dapat mandiri dalam segala hal yang berhubungan dengan kehidupannya. Bahkan cenderung memiliki ketakutan terhadap kemandirian (Iswantiningrum, 2013).

Jika berbicara soal kemandirian, sebenarnya dalam ajaran agama Islam sendiri sangat menekankan pentingnya kemandirian. Salah satu etos yang ada dalam ajaran agama Islam adalah manusia dapat berbuat sesuatu untuk orang lain dan menghindarkan diri dari meminta-minta kepada orang lain (Putro, 2010). Menariknya terdapat salah satu ayat dalam al-Quran yang sering dipakai untuk menegaskan perbedaan sektor tugas antara laki-laki dan perempuan, yaitu Q.S. an-Nisā ayat 34: 


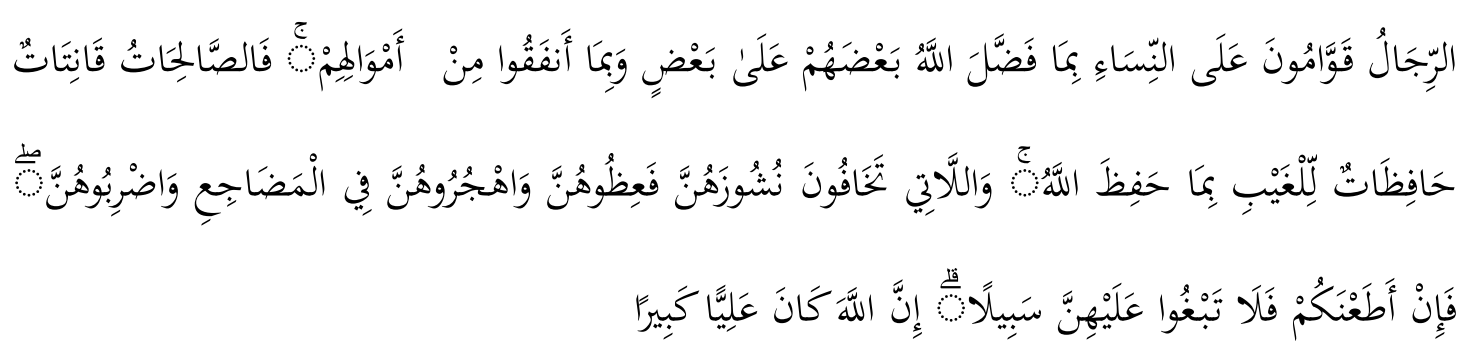

"Kaum laki-laki itu adalah pemimpin bagi kaum wanita, oleh karena Allah telah melebihkan sebagian mereka (laki-laki) atas sebagian yang lain (wanita), dan karena mereka (laki-laki) telah menafkahkan sebagian dari harta mereka. Sebab itu maka wanita yang saleh, ialah yang taat kepada Allah lagi memelihara diri ketika suaminya tidak ada, oleh karena Allah telah memelihara (mereka). Wanitawanita yang kamu khawatirkan nusyuznya, maka nasehatilah mereka dan pisahkanlah mereka di tempat tidur mereka, dan pukullah mereka. Kemudian jika mereka mentaatimu, maka janganlah kamu mencari-cari jalan untuk menyusahkannya. Sesungguhnya Allah Maha Tinggi lagi Maha Besar".

Q.S. an-Nisā ayat 34 seringkali hanya dipahami secara tekstual dan parsial oleh banyak kalangan. Kemudian dijadikan dasar dalam membedakan kedudukan antara laki-laki dan perempuan serta menjadi justifikasi bahwa kepemimpinan hanya dimiliki laki-laki (Subhan, 2008). Padahal jika mencermati penjelasan yang terdapat dalam Tafsir Al-Misbah tentang ayat ini, dijelaskan memang ada perbedaan tugas antara laki-laki dan perempuan. Jika dalam konteks berumah tangga maka tidak ada tawar menawar terhadap kepemimpinan laki-laki. Ada perbedaan tertentu baik fisik maupun psikis terhadap laki-laki dan perempuan. Mempersamakannya dalam segala hal juga tidak dibenarkan karena akan melahirkan jenis ketiga yang bukan laki-laki maupun perempuan (Syihab, 2007).

Jadi dapat disimpulkan bahwa Q.S. an-Nisā ayat 34 bukan hanya menitikberatkan pada perbedaan laki-laki dan perempuan sesuai dengan kodratnya masing-masing. Namun lebih kepada penegasan bahwa laki-laki sebagai pemimpin dalam rumah tangga memiliki kewajiban dan kewenangan untuk mendidik istrinya. Selain itu kesalahan dalam memahami Q.S. an-Nisā ayat 34 serta sumber tuntunan lainnya dalam agama Islam dikhawatirkan akan membuat kesempatan para perempuan untuk berpikir dan berperan aktif pada ranah yang lebih luas menjadi sangat terbatas, tidak menutup kemungkinan akan membuat perempuan justru mengalami permasalahan dalam hal kemandirian.

Permasalahan pada kemandirian dan ketergantungan secara psikis pada lingkungan sekitar maupun orang terdekat bisa menjadi masalah yang amat serius bagi perempuan. Istilah yang berkaitan erat dengan permasalahan ini adalah cinderella complex syndrome. 
Menurut Collete Dowling dalam bukunya yang berjudul "The Cinderella Complex: Womens Hidden Fear of Independence (Tantangan Wanita Modern: Ketakutan Wanita akan Kemandirian)", cinderella complex atau cinderella complex syndrome ialah kecenderungan perempuan untuk tergantung secara psikis, hal ini terjadi karena yang ada dalam pikiran mereka adalah keinginan untuk selalu diselamatkan, dilindungi, dan tentunya disayangi oleh orangtua, sahabat, atau pasangannya. Sesuai yang dikemukakan oleh Alexandra Symonds dalam penelitiannya bahwa cinderella complex merupakan masalah dari hampir semua perempuan yang ditemuinya, bahkan perempuan yang dari luar tampak berhasil sekalipun juga cenderung untuk merendahkan diri mereka kepada orang lain, menjadi tergantung dan tanpa sadar mengabdikan sebagian besar energi mereka untuk mendapatkan cinta, pertolongan dan perlindungan terhadap apa yang kelihatannya sulit dan menantang dunia (Hapsah, 2014).

Jika lebih lanjut dikaitkan dengan kehidupan anggota sebuah organisasi. Idealnya organisasi juga dapat memberikan sumbangsih yang besar dalam hal kemandirian. Sesuai dengan fungsi dari organisasi itu sendiri yang menjadi tempat pembelajaran, melatih seseorang menjadi lebih mandiri, dan berkembang sesuai dengan kemampuannya masingmasing (Maulidy, 2019).

Oleh karenanya cukup mengherankan apabila ada anggota organisasi yang terindikasi mengalami cinderella complex syndrome, apalagi jika jumlah anggota perempuan jauh lebih banyak dibanding jumlah anggota laki-laki yang dimana seharusnya kesempatan anggota perempuan untuk mengembangkan potensi diri dan meningkatkan kemandirian sangat terbuka lebar.

Lebih menarik lagi adalah hasil screening test menggunakan skala yang dilakukan pada seluruh anggota perempuan KAMMI Kota Banjarmasin keturunan suku Banjar. Cinderella complex syndrome dapat dilihat dari lima aspek yaitu rendahnya harga diri, tergantung kepada orang lain, mengharapkan pengarahan dari orang lain, kontrol diri eksternal, menghindari tantangan, dan kompetisi. Skala tersebut memiliki jumlah item sebanyak 33 item yang memiliki koefisien, dengan kisaran nilai, sebesar 0,274 sampai dengan 0,763 dan koefisien reliabilitas sebesar 0,876 dan memiliki skor tertinggi 4 dan skor terendah 1 pada masingmasing item. Dan berikut ini pengkategorisasian distribusi cinderella complex syndrome yang dilakukan secara manual. 
Pada skala ini terdapat tiga kategori tingkat cinderella complex syndrome yakni kategori rendah, sedang, dan tinggi. Tidak ada kategorisasi normal karena skor terendah pada angka 0 sekalipun masih dikategorikan rendah dan bukan normal sama sekali. Hal ini karena diyakini bibit cinderella complex syndrome ini ada pada hampir setiap perempuan, setelah berbagai penyelidikan dan penelitian dapat diketahui bahwa ternyata sindrom ini dialami oleh banyak perempuan, bahkan sudah mendarah daging pada diri perempuan di seluruh dunia dan seluruh kebudayaan. Namun, perempuan seringkali tidak menyadarinya. Menurut Alexandra Symond, cinderella complex syndrome adalah masalah yang ada pada hampir setiap wanita yang pernah ia temui (Dowling, 1981).

Hasil yang didapatkan setelah pengujian ini, dapat dilihat bahwa memang para anggota perempuan ini mengalami cinderella complex syndrome. Hasil yang didapatkan adalah sebagai berikut:

\section{Tabel 1.1}

Gambaran Umum Cinderella Complex Syndrome pada anggota perempuan KAMMI kota Banjarmasin

\begin{tabular}{cccc}
\hline \multirow{2}{*}{ Interval Skor } & Kriteria & \multicolumn{2}{c}{ Cinderella Complex } \\
\cline { 3 - 4 } & & F & $\%$ \\
\hline $99 \leq X$ & Tinggi & - & 0 \\
$99 \leq \mathrm{X}<66$ & Sedang & 11 & 78,6 \\
$\mathrm{X}<66$ & Rendah & 3 & 21,4 \\
\hline \multicolumn{2}{r}{ Jumlah } & 14 & 100 \\
\hline
\end{tabular}

Berdasarkan hasil dari screening test tersebut dapat diketahui bahwa cinderella complex syndrome pada perempuansuku Banjar anggota KAMMI Kota Banjarmasin pada kategori sedang sebanyak 78,6\% (11 orang), dan pada kategori rendah sebanyak 21,4\% (3 orang). Dari hasil tersebut sementara ini dapat disimpulkan bahwa cinderella complex syndrome pada perempuan suku Banjar anggota KAMMI Kota Banjarmasin sebagian besar berada pada kategori sedang.

Berdasarkan latar belakang tersebut, maka peneliti tertarik untuk membahas dan mengkaji lebih dalam tentang bagaimana gambaran Psikologis cinderella complex syndrome pada perempuan suku Banjar khususnya pada anggota organisasi KAMMI Kota Banjarmasin 
yang berjudul "Gambaran Psikologis Cinderella Complex Syndrome pada Perempuan Suku Banjar (Studi Deskriptif pada KAMMI Kota Banjarmasin)."

\section{Metode}

Jenis penelitian ini adalah penelitian lapangan (field reseach) yang menggunakan informasi yang diperoleh dari lapangan secara langsung (Rahmadi, 2011), yang bekenaan dengan gambaran psikologis cinderella complex syndrome. Penelitian ini merupakan penelitian kualitatif deskriptif yakni jenis penelitian yang tujuannya untuk menyajikan gambaran lengkap mengenai setting sosial atau dimaksudkan untuk eksplorasi dan klarifikasi mengenai suatu fenomena atau kenyataan sosial, dengan jalan mendeskripsikan sejumlah variabel yang berkenaan dengan masalah dan unit yang diteliti antara fenomena yang diuji. Teknik yang digunakan yaitu teknik purposeful sampling yang berdasarkan pada ciri-ciri yang dimiliki oleh subjek yaitu subjek yakni anggota KAMMI Kota Banjarmasin yang masuk kategori remaja akhir/dewasa awal (usia 16-25 tahun), memang memiliki cinderella complex syndrome yang telah diuji kecenderungannya menggunakan skala cinderella complex syndrome, bersuku Banjar, ayah dan ibu asli orang Banjar, berbahasa Banjar. Subjek ini didapatkan setelah melalui proses screening test menggunakan skala cinderella complex syndrome setelah sebelumnya dilakukan wawancara pada 14 orang perempuan anggota KAMMI keturunan suku Banjar. Teknik pengumpulan data yang digunakan yaitu, screening test menggunakan skala, wawancara, observasi, dan tes grafis yang diinterpretasi oleh 2 orang psikolog.

\section{H a s i 1}

Setelah dilakukan penggalian data dan pengolahan data yang peneliti lakukan terhadap dua orang yang menjadi subjek penelitian yakni subjek D dan subjek J, dapat diketahui bahwa proses terbentuknya cinderella complex syndrome pada kedua subjek cukup erat dengan perbedaan perlakuan antara anak laki-laki dan perempuan atau pada saudara lain yang dialami sejak kecil. Pada subjek D banyak terdapat luka masa lalu yang belum terselesaikan dan pada subjek J kebiasaan-kebiasaan yang diterapkan sejak kecil juga cukup berperan. Adapun faktor yang berpengaruh adalah pola asuh otoriter oran gtua yang juga dipengaruhi oleh budaya seperti yang dialami oleh subjek D yang sejak kecil hampir tidak memiliki pilihan karena selalu dikendalikan oleh orang tua, selain itu rendahnya harga diri 
juga sangat mempengaruhi subjek untuk tidak berani mengambil keputusan, tantangan, bahkan kesempatan yang terbuka lebar. Sedangkan pada subjek J yang pola asuh orang tuanya cenderung permisif, faktor rendahnya harga diri, media massa dan lingkungan pergaulan yang ternyata sangat berpengaruh. Ciri-ciri yang Nampak dari kedua subjek adalah tidak percaya diri, merasa tidak berharga (inferior), takut menyelesaikan dan menghadapi tantangan, cukup sulit melakukan segala sesuatu sendiri, seringkali mengalami psikosomatis terkhusus pada subjek D, sangat takut gagal, malas mengambil resiko, tergantung pada bagaimana teman dan lingkungan (dependen), kadangkala atau bahkan sering berfikiran untuk mengakhiri hidup. Aspek yang terlihat yakni mengharapkan pengarahan dari orang lain, kontrol diri eksternal, rendahnya harga diri, serta menghindari tantangan dan kompetisi.

Hasil tes grafis kedua subjek juga terbilang memiliki keselarasan dengan hasil wawancara. Subjek D, tergambar seringkali merasa takut dan cemas akan tantangan, kesulitan mengekspresikan apa yang dirasakan, masih kekanak-kanakan, sangat mudah merasa minder atau tidak berharga. Selain itu, subjek D memiliki hambatan dalam problem solving. Kesulitan untuk menggambarkan sosok laki-laki yang dapat menjadi pelindung dalam imajinasinya. Pasif dan lambat dalam mengambil suatu keputusan atau tindakan. Lebih suka meminta pendapat dan pengarahan dari orang lain. Subjek D memiliki rasa tidak percaya diri dalam melakukan kontak sosial dan merasa tidak memiliki sesuatu yang dapat dibanggakan pada lingkungan. Berusaha terlihat kuat dan bertumbuh tetapi sebenarnya banyak menyimpan luka.

Sedangkan subjek J mampu mengontrol emosi dan mengekspresikan perasaan dengan orang sekitar, sangat takut gagal, seringkali merasa takut dan cemas jika menghadapi suatu keadaan yang berkaitan dengan resiko dan tantangan, kekanak-kanakan, senang menonjol, senang diperhatikan (bahkan jika ada yang tidak memperhatikan akan cenderung merasa tidak nyaman), belum memahami bagaimana body image-nya sendiri. Takut perhatian yang telah didapatkan akan hilang. Sangat merindukan sosok seorang ayah. Memiliki energi yang besar yang kadang digunakan untuk meregulasi kecemasan yang dialami, sehingga seringkali menyebabkan kelelahan psikis. Subjek J tidak memiliki hambatan dalam memahami dan menyelesaikan sesuatu. Cukup aktif dengan inisiatif dan kemampuan pemecahan masalah yang baik, tetapi lambat dalam mengambil keputusan atau tindakan. 
Lebih suka meminta pendapat dan pengarahan dari orang lain. Tergambar sebagai orang yang sangat dependen. Hanya bergerak sesuai dengan apa yang dipikirkan dan dikehendaki. Subjek J juga tergambar sebagai orang cukup mudah bergaul dan bersosialisasi, lebih senang jika kegiatannya ditemani oleh orang lain. Cukup berusaha untuk menjalin interaksi sosial dengan lingkungan, keinginan untuk menonjol, diperhatikan, dan dianggap ada sangat besar.

\section{Pembahasan}

Berdasarkan hasil wawancara dan tes grafis yang dilakukan peneliti untuk mengetahui gambaran psikologis cinderella complex syndrome, maka dapat diketahui bagaimana proses terbentuk, faktor-faktor yang mempengaruhi, ciri-ciri, aspek cinderella complex syndrome, serta gambaran kepribadian subjek yang meliputi aspek kognitif, emosi, dan sosial.

Perlu dipahami terlebih dahulu bahwa yang melatarbelakangi terbentuknya cinderella complex syndrome adalah karena perbedaan perlakuan yang didapat oleh anak laki-laki dan anak perempuan sejak kecil. Menurut Atkinson, setiap budaya mempunyai batasan-batasan dalam mengatasi masalah tersebut. Namun bagaimana pun bentuknya, setiap kultur masih akan menjadikan bayi laki-laki dan perempuan menjadi dewasa yang maskulin dan feminin (Putri, 2017).

Pada kedua subjek meski sama-sama berlatar belakang keluarga dari suku Banjar yang terbilang menjunjung adat istiadat, ada perbedaan yang signifikan. Subjek D berlatar belakang keluarga dengan pola asuh otoriter terbiasa diarahkan dan diatur dalam banyak hal. Meskipun subjek tidak menyukai pengaturan ini nyatanya subjek tidak berani untuk menyuarakan pendapatnya karena takut akan dimarahi. Sedangkan subjek J berlatar belakang keluarga dengan gaya pola asuh permisif dimana segala hal masih diberikan kebebasan untuk memilih, tetapi tetap ada pengarahan dan diskusi untuk mengambil sebuah keputusan terbaik.

Menurut Dowling, ketakutan dan ketergantungan telah lama dianggap menjadi hal yang wajar bagi para perempuan. Bagaimana cara orang tua dalam mengasuh dan mendidik anak semasa kecil akan sangat mempengaruhi kemandirian mereka ketika mencapai usia dewasa. Hal ini berkaitan dengan kebutuhan dari individu itu sendiri. Kebutuhan-kebutuhan tersebut menetap dan menuntut untuk dipenuhi bersamaan dengan kebutuhan kita akan kemandirian. Ketika seseorang membutuhkan bantuan orang lain sebenarnya adalah hal yang wajar, 
namun ketika individu sepenuhnya menyandarkan harapan baik dalam bentuk moril, materi, maupun spiritual pada orang lain, maka perilaku tersebut sudah termasuk maladaptif (Anggreini Ade Putri, 2017).

Pada kedua subjek, baik subjek D maupun subjek J sejak kecil mampu memahami bahwa hal yang wajar jika anak perempuan berada di ranah domestik, lebih diperhatikan, dan dilindungi dibandingkan anak laki-laki. Subjek D meskipun terbiasa melakukan segala pekerjaan rumah sendiri dan mengaku tidak terbiasa dilindungi maupun diperhatikan sejak kecil, akan tetapi faktanya tidak dapat menguasai rasa takut dan ketergantungannya dengan orang lain. Oleh karenanya ketika berada di luar rumah, dalam forum atau kegiatan selain yang berhubungan dengan keluarga, subjek kurang dapat menyelesaikan segala sesuatu seorang diri jika tanpa pendampingan dan pengarahan. Sedangkan pada subjek J, justru dari pihak orangtua terutama ibu subjek yang memberikan pandangan bahwa perempuan memang tidak bisa tidak bergantung dengan laki-laki, karena ibu subjek berpandangan bahwa akan sulit menjalani hidup jika tanpa adanya laki-laki.

Adapun faktor-faktor yang mempengaruhi cinderella complex syndrome menurut Santoso, A.A, Rustam, A., dan Setiowati, A.E. yaitu pola asuh orang tua, media komunikasi dan media massa, pekerjaan atau tugas yang menuntut pribadi, dan agama. Adapun menurut Dowling adalah faktor budaya, pola asuh, media massa dan harga diri yang mempengaruhi cinderella complex syndrome muncul atau berkembang dalam diri seseorang (Putri, 2017).

Pada subjek D, dari hasil wawancara dapat diketahui bahwa subjek merasakan pola pengasuhan yang cenderung otoriter. Hal ini yang salah satunya kemudian menyebabkan subjek akhirnya mengalami cinderella complex syndrome. Hal ini sejalan dengan banyak penelitian terdahulu yang membuktikan bahwa orang tua dengan pola asuh otoriterlah yang akan berbanding lurus dengan kecenderungan cinderella complex syndrome pada seseorang. Semakin orang tua melakukan pola asuh otoriter kepada anak, maka semakin tinggi kecenderungan anak untuk terkena cinderella complex syndrome, karena anak yang sudah sangat diatur oleh orang tua sedemikian rupa menjadikan anak tidak dapat mengembangkan kreatifitas dan pendapatnya sendiri, hal ini mengakibatkan anak kehilangan kepercayaan diri dan menjadi tidak mandiri (Putri, 2017).

Selain itu, harga diri subjek D cukup rendah. Subjek merasa kurang berharga dan dihargai. Subjek mengaku seringkali berpikir untuk mengakhiri hidupnya karena merasa 
tidak berguna dan lelah dengan segala permasalahan yang harus dihadapi. Subjek seringkali sakit karena terlalu memikirkan sesuatu hal tetapi tanpa disertai upaya pemecahan masalah yang serius. Sedangkan pada subjek J, subjek mengakui bahwa selama hidup subjek pernah berpikir untuk mengakhiri hidupnya dikarenakan subjek melakukan kesalahan yang cukup fatal sehingga membuat kedua orang tua subjek menjadi marah besar.

Pada subjek J faktor media massa menjadi acuan subjek dalam berfikir dan mengambil tindakan. Subjek mengaku bahwa apa yang subjek tonton dan saksikan akhirnya terinternalisasi ke dalam dirinya sehingga mempengaruhinya dalam bertingkah laku. Selain itu salah satu organisasi yang diikutinya menjadikan pandangannya terhadap perempuan banyak berubah. Subjek memahami bahwa sebagai seorang muslimah banyak batasan yang harus diperhatikan. Bagaimana seorang muslimah harus bertingkah laku, karena menurut subjek secara kodrati perempuan memang seharusnya tidak bisa banyak menampakkan diri. Subjek merasa semenjak ikut organisasi ini subjek jadi lebih malas keluar rumah dan berkegiatan meskipun saat di rumah nyatanya tidak ada hal yang dilakukan juga.

Pada kedua subjek, ciri-ciri yang paling nampak adalah kurang percaya pada kemampuan diri sendiri. Pada subjek D rasa tidak percaya pada kemampuan sendiri ini cukup sering dirasakan. Subjek mengatakan karena di rumah subjek terbiasa diremehkan sehingga subjek merasa memang kurang bisa melakukan banyak hal dan cenderung takut menyelesaikan sesuatu atau mengambil sebuah tantangan untuk dilakukan. Sedangkan pada subjek J, subjek mengaku sangat takut gagal dan malas mengambil resiko karena subjek lebih suka berada pada zona nyaman. Subjek seringkali merasa kurang percaya diri apabila dimintai tolong tentang sesuatu. Jika subjek merasa kurang paham atau kurang persiapan, maka subjek cenderung akan menghindari permintaan tolong tersebut. Selain itu, subjek D adalah tipikal yang sulit melakukan segala sesuatu sendiri dan menunggu arahan penuh atau mengerjakan sesuatu jika memang disuruh. Karena menurut subjek jika banyak inisiatif maka semakin banyak pula pekerjaan yang akan dibebankan.

Pada subjek J, subjek mengaku lebih suka dan sering melakukan segala sesuatu ditemani oleh orang lain. Hal ini karena subjek orang yang tergantung pada bagaimana teman dan lingkungannya. Subjek adalah orang yang takut gagal dan malas mengambil resiko. Subjek sangat senang meminta pendapat untuk menguatkan argumennya terhadap sesuatu hal. Bagi kedua subjek banyak hal yang menjadi alasan mengapa mereka takut untuk 
mengambil dan menghadapi tantangan kehidupan, hal ini dikarenakan keyakinan bahwa mereka akan sulit menyelesaikan tantangan tersebut. Kedua subjek cenderung tidak percaya pada diri sendiri.

Ciri-ciri yang diperlihatkan oleh subjek sesuai dengan ciri-ciri perempuan yang mengalami cinderella complex syndrome menurut Dowling, dimana biasanya perempuan yang mengalami cinderella complex syndrome kurang percaya pada kemampuan diri sendiri, kurang atau bahkan tidak mampu melakukan sesuatu hal sendirian, memiliki keyakinan bahwa hanya pertolongan orang lain yang bisa membantunya, selain itu, cinderella complex syndrome juga ditandai dengan adanya keyakinan bahwa dia tidak akan berhasil menghadapi tantangan kehidupan. Selain itu juga sepenuhnya hal yang menyangkut dengan kehidupannya akan digantungkan kepada laki-laki, karena menganggap laki-laki adalah sosok yang kuat dan bisa dijadikan tempat bergantung (Putri, 2017).

Adapun aspek-aspek yang terdapat pada Cinderella Complex Syndrome adalah cenderung merendahkan diri kepada orang lain, tidak mandiri, ingin mendapatkan cinta, pertolongan, dan perlindungan, mengharapkan pengarahan dari orang lain, kontrol diri eksternal, rendahnya harga diri, menghindari tantangan dan kompetisi, mengandalkan laki-laki, dan ketakutan kehilangan feminitas (Hapsah, 2014).

Pada kedua subjek aspek-aspek yang terlihat dan berhasil peneliti gali selama proses wawancara dan observasi ada beberapa. Diantaranya adalah aspek cenderung merendahkan diri dengan orang lain dan tidak mandiri. Pada subjek D, subjek cenderung merasa tidak dapat melakukan banyak hal dibandingkan orang lain, merasa bukan apa-apa bahkan tidak berguna sebagai seorang manusia. Pada subjek J hal ini kurang begitu nampak. Subjek J mengaku cukup mandiri dalam melakukan banyak hal, meskipun kadang perlu ditemani karena subjek lebih suka bersama teman daripada sendiri, diberikan banyak pengarahan dan pendapat dari orang lain.

Pada aspek lain seperti ingin mendapatkan cinta, pertolongan, dan perlindungan cukup nampak pada kedua subjek. Pada subjek D rasa ingin mendapatkan cinta atau kasih sayang muncul karena selama hidupnya subjek kurang mendapatkan hal ini dari paman dan bibi yang seharusnya menjadi pengganti orang tua. Sedangkan ia jarang bisa pulang ke rumah orang tuanya meskipun jaraknya cukup dekat dan hubungannya dengan ibu tidak begitu dekat. Subjek D sering merasa perlu banyak pertolongan, karena kepercayaannya terhadap 
diri sendiri dan kemampuan pemecahan masalahnya cukup rendah. Subjek juga ingin mendapatkan perlindungan, karena perlakuan yang subjek dapatkan membuatnya merasa lemah. Pada subjek J keinginan mendapatkan cinta, kasih sayang, dan pertolongan muncul karena pandangan subjek terhadap sosok seorang perempuan itu sendiri. Yang mana menurut subjek wajar jika perempuan itu ingin disayang, ingin ditolong, dan dilindungi karena perempuan memang kodratnya harus dilindungi dan disayangi.

Pada aspek lainnya yakni, mengharapkan pengarahan dari orang lain, kedua subjek sama-sama memperlihatkan aspek ini. Pada subjek D pengarahan dari orang lain sangat berperan dalam penyelesaian masalah dan pengambilan keputusan subjek. Tanpa pengarahan, subjek cenderung pasif dan tidak berani mengambil langkah. Pada subjek J pengarahan dari orang lain juga dianggap sangat penting, karena dengan mendapatkan pengarahan, perasaan takut subjek pada kegagalan dan resiko bisa jauh berkurang.

Adapun pada aspek seperti kontrol diri eksternal juga cukup terlihat pada kedua subjek. Aspek ini terlihat ketika perempuan mendapatkan keberhasilan, dirinya berhenti pada titik tertentu dan tidak ingin meraih keberhasilan yang lebih jauh lagi. Pada aspek rendahnya harga diri, pada diri perempuan terdapat kurangnya harga diri, akibatnya seringkali menekan inisiatif dan membuang aspirasinya. Hal ini terkait juga dengan perasaan tidak aman yang sangat mendalam serta ketidakpastian mengenai kemampuan serta nilai diri mereka (Hapsah, 2014). Hal ini terlihat pada saat proses wawancara dan observasi dimana kedua subjek memiliki harga diri yang cukup rendah terlebih pada subjek $D$, sehingga para subjek lebih senang menekan inisiatif yang dimiliki dan membuang aspirasi atau mengatakannya kepada orang lain yang dipercaya untuk menyampaikan kepada banyak orang seperti yang dilakukan oleh subjek J. Subjek D merasa kemampuan dan nilai dirinya rendah dibandingkan orang lain, sehingga subjek seringkali merasa tidak berharga dan tidak berguna.

Pada aspek menghindari tantangan dan kompetisi. Kedua subjek secara gamblang menyampaikan bahwa tidak menyukai tantangan dan kompetisi terutama pada subjek J yang mengemukakan bahwa ia adalah pribadi yang sangat takut akan kegagalan dan malas untuk mengambil sebuah resiko. Hal ini sesuai dengan teori pada aspek cinderella complex syndrome, bahwa menghindari tantangan dan kompetisi terkait dengan faktor emosional seperti takut salah, merasa tidak enak dengan teman, tidak bersemangat, dan kurangnya 
optimisme dalam hiduplah yang seringkali menghalangi kompetensi mereka untuk menghadapi ketakutan, persaingan, dan terus maju menghadapi segala rintangan (Hapsah, 2014).

Menurut Anggriany dan Astuti, cinderella complex syndrome dinilai memiliki dampak yang buruk bagi perkembangan perempuan, diantaranya mempengaruhi cara perempuan memberikan respon terhadap lingkungannya. Juga berdampak pada produktivitas perempuan seperti menghambat semua jenis kemampuan perempuan, menghambat untuk menjadi diri sendiri, menjadi kurang bersemangat, dan kurang berkomitmen dalam lingkungan kerjanya. Bagi perempuan di perguruan tinggi, cinderella complex syndrome dapat menjadi salah satu penyebab terjadinya prokrastinasi akademik. Seseorang yang mengalami cinderella complex syndrome, akan merasa dirinya tidak berdaya (Oktinisa dkk., 2017).

Berbicara soal cinderella complex syndrome dalam perspektif Islam. Dalam agama Islam, baik perempuan maupun laki-laki dianjurkan untuk memiliki kemandirian. Islam sangat menekankan pentingnya kemandirian. Salah satu etos yang ada dalam ajaran agama Islam adalah manusia dapat berbuat sesuatu untuk orang lain dan menghindarkan diri dari meminta-minta kepada orang lain. Dalam agama Islam seseorang juga didorong untuk bebas, inisiatif, percaya diri, dan memiliki pengendalian diri. Bila ajaran-ajaran agama Islam ini dipahami dan dihayati oleh individu dalam sekolah maupun masyarakat, maka mereka akan menjadikan ajaran itu sebagai bagian dari sifat-sifat kepribadiannya yang menghasilkan pribadi-pribadi yang mandiri (Putro, 2010).

Maka, menurut hemat peneliti, tidak sesuai jika cinderella complex sydrome ini disepelekan keberadaannya apalagi dianggap sebagai karakteristik dari perempuan muslimah yang memahami bahwa agama Islam memberikan batasan-batasan yang tidak boleh diterobos oleh kaum perempuan, hingga tidak jarang menjadikan perempuan enggan memaksimalkan potensi yang dimilikinya sebagai seorang manusia bahkan sampai menyebabkan gangguan pada kemandirian. Karena agama Islam justru menekankan soal kemandirian tanpa kecuali.

Agama Islam sendiri juga tidak mungkin menjadikan kaum perempuan sebagai manusia kelas kedua setelah laki-laki, karena nyatanya banyak sekali ayat yang menggambarkan tentang kemuliaan dan keutamaan perempuan. Maka adanya kesalahpahaman di masyarakat tentang peran dan posisi perempuan apalagi sampai 
menimbulkan pandangan bahwa perempuan adalah makhluk kelas kedua setelah laki-laki dapat disinyalir salah satu penyebabnya adalah karena kesalahpahaman dalam memaknai dalil-dalil dalam kitab suci al-Quran dan pengaruh budaya dan kebiasaan yang masih dipertahankan.

Pada laki-laki dan perempuan memang ada pembagian tugas yang tak dapat ditawarmenawar seperti fungsi dan tugas perempuan yang kodratnya menjadi seorang ibu yang akan mengandung, melahirkan, dan menyusui tidak dapat digantikan kedudukannya oleh kaum laki-laki sampai kapan pun. Sebaliknya peran dan tanggung jawab seorang laki-laki yang akan menjadi imam (pemimpin) dalam rumah tangga juga tidak dapat digantikan oleh perempuan. Namun, bukan berarti dengan adanya pembagian tugas ini kemudian membatasi kemampuan perempuan untuk berkiprah dalam berbagai bidang yang sebenarnya mampu memberikan banyak kebermanfaatan untuk masyarakat luas.

Oleh karenanya, peneliti ingin menegaskan bahwa adanya penelitian ini bukan untuk mengedepankankan kesetaraan tanpa pilah bagi kaum perempuan. Peneliti ingin memaparkan bahwa terdapat sebuah gangguan yang justru dianggap sepele dan wajar oleh banyak pihak. Padahal apabila dibiarkan akan menimbulkan dampak yang serius bagi perkembangan kepribadian perempuan.

Selanjutnya, berbicara soal dampak, pada akhirnya peneliti menyadari cinderella complex syndrome ini akhirnya banyak mempengaruhi kehidupan berorganisasi kedua subjek saat berada di KAMMI Kota Banjarmasin. Sebagai seorang anggota kader KAMMI dituntut untuk mampu menjadi seorang pemimpin baik itu anggota laki-laki maupun perempuan sesuai dengan visi organisasi yakni mencetak kader-kader pemimpin. Kedua subjek akhirnya merasa cukup kesulitan menyesuaikan diri saat berada di organisasi KAMMI yang meski secara jumlah kenyataannya lebih banyak perempuan daripada lakilaki. Pada kedua subjek diketahui bahwa selama masa kepengurusan berjalan perannya yang sebenarnya sangat strategis tidak dimaksimalkan dengan sebaik mungkin. Pada kedua subjek sering muncul perasaan enggan untuk memaksimalkan potensi diri karena merasa sebagai seorang perempuan hal ini tidak begitu perlu.

Berdasarkan uraian temuan di atas, dapat divisualisasikan dalam skema yang merangkum narasi tentang gambaran psikologis cinderella complex syndrome pada perempuan suku Banjar. 


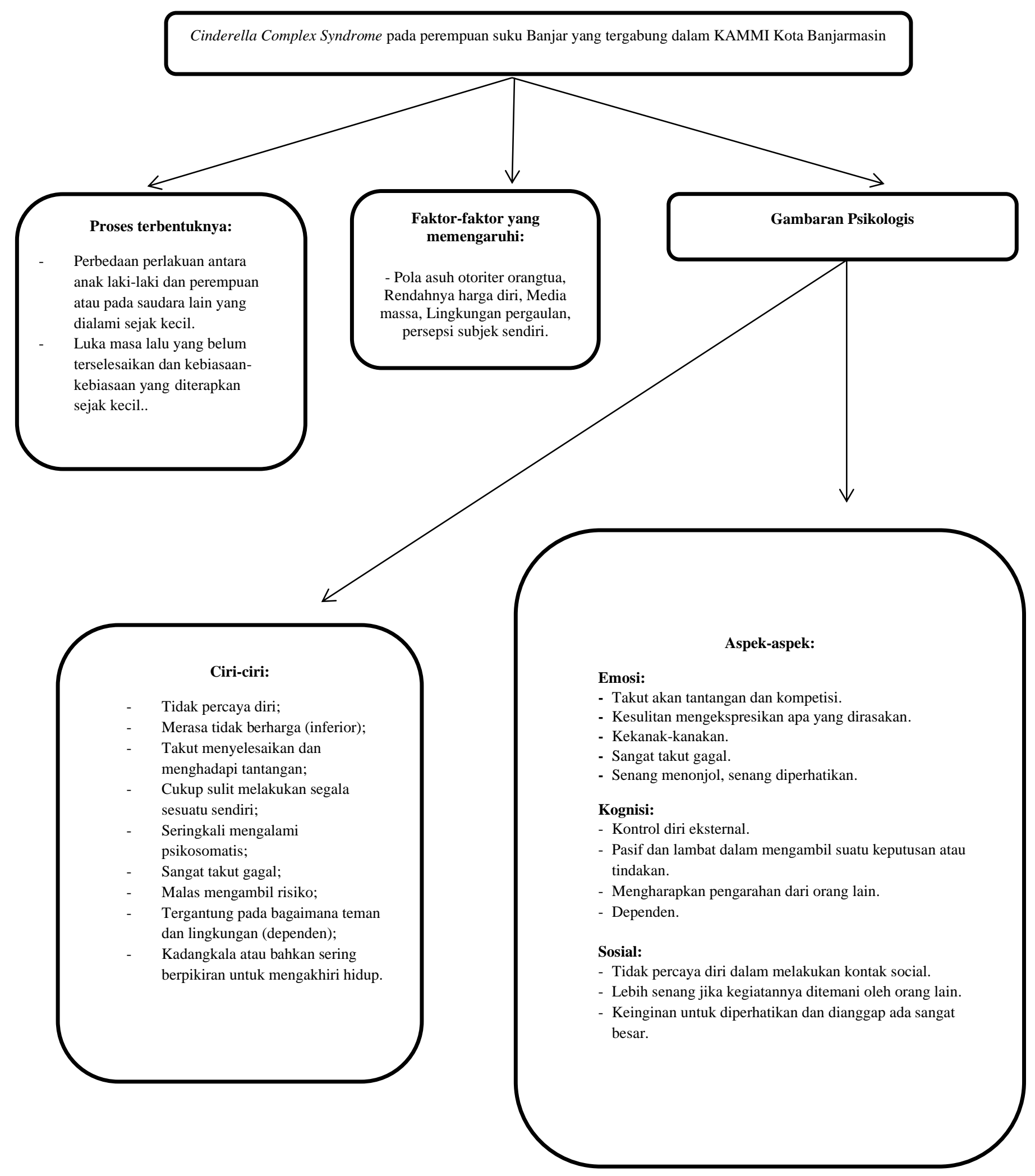




\section{Kesimpulan}

Berdasarkan hasil penelitian dapat diambil kesimpulan bahwa terbentuknya cinderella complex syndrome berawal dari perbedaan perlakuan, entah pada anak laki-laki dan perempuan serta pengalaman-pengalaman masa kecil. Kedua subjek, sejak kecil memahami bahwa hal yang wajar jika anak perempuan berada di ranah domestik, lebih diperhatikan, dan dilindungi dibandingkan anak laki-laki. Faktor yang mempengaruhi adalah pola asuh orang tua, rendahnya harga diri, media massa, lingkungan pergaulan, dan persepsi subjek. Ciri-ciri yang terlihat yakni tidak percaya pada kemampuan sendiri, sering kali merasa tidak berharga (inferior), merasa kurang bisa melakukan banyak hal dan cenderung takut menyelesaikan dan menghadapi tantangan, cukup sulit melakukan segala sesuatu sendiri, menunggu arahan penuh, kurang bahkan tidak ada inisiatif, seringkali mengalami psikosomatis, sangat takut gagal, malas mengambil resiko, lebih suka melakukan segala sesuatu ditemani oleh orang lain, dependen, sangat senang meminta penguatan dan solusi dari orang lain, serta lebih senang menekan inisiatif yang dimiliki dan membuang aspirasi yang dimilikinya. Aspek yang terlihat selama proses penelitian berlangsung adalah aspek mengharapkan pengarahan dari orang lain, kontrol diri eksternal, rendahnya harga diri serta menghindari tantangan dan kompetisi, juga terdapat aspek emosi, kognitif, dan sosial yang berhasil diungkap melalui tes grafis.

\section{Saran}

Diharapkan subjek mampu mengembangkan kepribadian terutama aspek kemandirian dengan cara mencoba untuk lebih berani menghadapi segala macam masalah dan tantangan kehidupan. Pada subjek D diharapkan agar dapat lebih banyak berinteraksi dengan lingkungan sosial dan masyarakat sehingga tidak memiliki hambatan dalam pergaulan serta meningkatkan kemampuan berkomunikasi dengan banyak orang. Pada subjek J diharapkan agar dapat meminimalisir rasa takut akan kegagalan dengan banyak latihan dan persiapan jika ingin menghadapi suatu tantangan. Bagi peneliti selanjutnya untuk lebih dapat menyempurnakan penelitian ini sehingga hasil yang diperoleh menjadi jauh lebih akurat. Agar penelitian dapat memberikan hasil yang lebih baik dan dapat digeneralisasi perlu dilakukan penelitian dalam cakupan yang lebih besar dan subjek yang dilibatkan adalah dengan kategori cinderella complex syndrome tinggi atau berat agar lebih banyak lagi ciri dan aspek yang dapat dilihat dan digali selama proses penelitian. Bagi KAMMI Kota Banjarmasin, diharapkan ada terobosan-terobosan dari organisasi terkait peningkatan kematangan beragama dan kepribadian para anggota khususnya anggota perempuan (akhwat), mengingat dua hal ini menjadi titik pangkal berkembang atau tidaknya cinderella complex syndrome pada diri seseorang. Hal ini mengingat populasi anggota perempuan yang dua kali lipat lebih banyak dibandingkan populasi anggota laki-laki, sehingga peneliti rasa amat disayangkan apabila tidak dimaksimalkan untuk kepentingan upaya perwujudan visi dan misi organisasi. 


\section{Referensi}

Dowling, C. (1981). Tantangan Wanita Modern: Ketakutan Wanita akan Kemandirian (Santi W.E. Soekanto, Penerj.). Jakarta: Erlangga.

Fatrawati Kumari. (2019, Agustus 28). Wawancara Pribadi dengan Salah satu Dosen sekaligus Peneliti dari LP2M UIN Antasari (Banjarmasin) [Komunikasi pribadi].

Hapsah, A. D. (2014). Cinderella Complex Pada Mahasiswi: Studi Deskriptif pada Mahasiswi di Universitas Negeri Semarang [Skripsi]. Universitas Negeri Semarang.

Iswantiningrum, F. D. P. (2013). Hubungan Antara Kematangan Kepribadian Dengan Kecenderungan Cinderella Complex Pada Mahasiswa di Asrama Putri Universitas Negeri Surabaya. Jurnal Mahasiswa Psikologi, 2(1).

Maulidy, B. (2019, Maret 19). Dampak Positif dan Negatif Organisasi Bagi Mahasiswa [Https://m.utak-atikotak.com/kongkow/detail/12480/Dampak-Positif-Dan-NegatifOrganisasi-Bagi-Mahasiswa].

Nuril Huda. (t.t.). Analisis Gender Baantaran Jujuran Dalam Kebudayaan Banjar", Jurnal Penelitian (Banjarmasin: Fakultas Dakwah dan Komunikasi IAIN Antasari Banjarmasin.).

Oktinisa, T. F., Rinaldi, \& Hermaleni, T. (2017). Kecenderungan Cinderella Complex Pada Mahasiswa Perempuan Ditinjau Dari Persepsi Pola Asuh. Jurnal Ilmiah RAP UNP, 8(2).

Putri, A. A. (2017). Cinderella Complex Syndrom pada Perempuan Minangkabau dengan Pola Asuh Otoriter [Skripsi]. Universitas Sumatera Utara.

Putro, M. H. K. (2010). Hubungan Antara Kematangan Beragama Dengan Cinderella Complex Pada Mahasiswi Fakultas Psikologi Universitas Muhammadiyah Surakarta. Jurnal Psikologi.

Salasiah. (2014). Peranan Perempuan Banjar Dalam Pendidikan Islam Abad XIX dan XX [Tesis]. Universitas Islam Negeri Antasari.

Subhan, Z. (2008). Menggagas Figh Pemberdayaan Perempuan. Jakarta: El Kahfi.

Syihab, M. Q. (2007). Tafsir Al-Misbah: Pesan, Kesan dan Keserasian Al-Qur'an. Tangerang: Lentera Hati. 


\begin{tabular}{|l|l|l|l|l|}
\hline Submit & Review & Revisi & Diterima & Publis \\
\hline $02-03-20$ & - & - & $25-03-21$ & $25-03-21$ \\
\hline
\end{tabular}

Ayu Nurhafizah, Siti Faridah, dan Imadduddin Program Studi Psikologi Islam

Fakultas Ushuluddin dan Humaniora

Universitas Islam Negeri Antasari Banjarmasin

Email: aidenhafizah@gmail.com 